\title{
Utilisation of Electrodialytically Treated Sewage Sludge Ash in Mortar
}

Kappel, Annemette; Pares Viader, Raimon; Kowalski, Krzysztof Piotr; Kirkelund, Gunvor Marie; Ottosen, Lisbeth M.

Published in:

Waste and Biomass Valorization

Link to article, DOI:

10.1007/s12649-018-0215-z

Publication date:

2018

Document Version

Peer reviewed version

Link back to DTU Orbit

Citation (APA):

Kappel, A., Pares Viader, R., Kowalski, K. P., Kirkelund, G. M., \& Ottosen, L. M. (2018). Utilisation of

Electrodialytically Treated Sewage Sludge Ash in Mortar. Waste and Biomass Valorization, 9(12), 2503-2515. https://doi.org/10.1007/s12649-018-0215-z

\section{General rights}

Copyright and moral rights for the publications made accessible in the public portal are retained by the authors and/or other copyright owners and it is a condition of accessing publications that users recognise and abide by the legal requirements associated with these rights.

- Users may download and print one copy of any publication from the public portal for the purpose of private study or research.

- You may not further distribute the material or use it for any profit-making activity or commercial gain

- You may freely distribute the URL identifying the publication in the public portal 


\section{Utilisation of electrodialytically treated sewage sludge ash in mortar}

2 Annemette Kappel, Raimon Parés Viader, Krzysztof Piotr Kowalski, Gunvor M. Kirkelund*, 3 Lisbeth M. Ottosen

4 Department of Civil Engineering, Technical University of Denmark, Brovej, build 118, 2800 Kgs. Lyngby, Denmark.*Corresponding author: gunki@byg.dtu.dk, phone +45 45251730

\section{ABSTRACT}

8 Phosphorous is a scarce resource and there is a need to develop methods for recovery of this irreplaceable nutrient from secondary resources, e.g. from sewage sludge ash (SSA). Today SSA is most often disposed of and the resource is lost. In the present study, about $90 \%$ phosphorous was recovered from SSA by electrodialytic separation in a bench scale set-up, and the particulate residue after the extraction (SSA-ED) was evaluated for use as cement replacement in mortar. The SSA-ED and untreated SSA were grinded for 0sec, $30 \mathrm{sec}$ and $10 \mathrm{~min}$ in order to obtain fractions with different degrees of fineness. Each fraction was tested as cement replacement with $20 \%$ substitution in mortar. The technical and aesthetical properties of mortars containing the two SSAs were compared to the properties of ordinary mortar. The SSA-ED was acidic; however, this did not significantly influence the mortar properties on short term investigated here. For example, the compressive strength of the mortar with SSA-ED only decreased by $8 \%$ compared to ordinary mortar. The workability of mortars with SSA or SSA-ED was reduced compared to the reference. The colour of mortar with SSA-ED was warm reddish, and more intense than the colour of the mortar with SSA. The intense colour was due to the increased concentration of hematite during ED. 
This study showed potential for separating SSA to two resources by combining electrodialytic extraction of phosphorous and subsequent utilization of the residual mineral ash in mortar.

Keywords: SSA, electrokinetic remediation, phosphorous, heavy metal, fineness

\section{Graphical abstract}

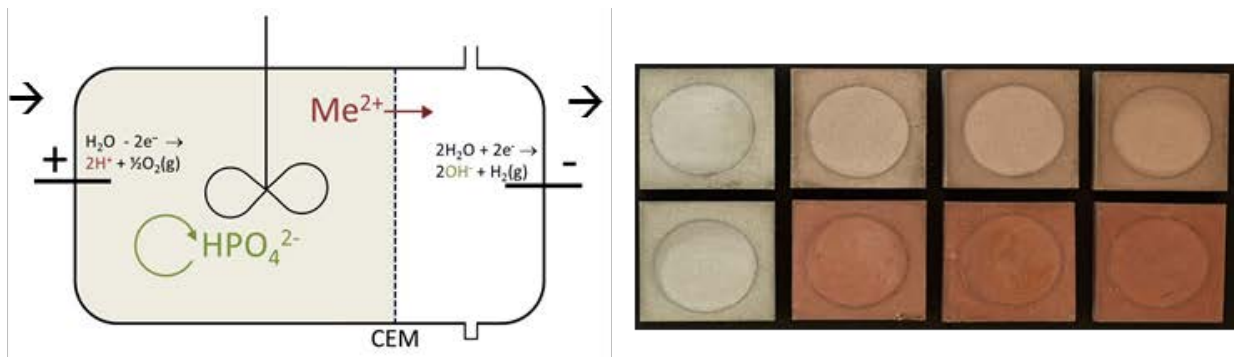

\section{INTRODUCTION}

Sewage sludge ash (SSA) is the residue from thermal treatment of sewage sludge, most frequently incineration, at wastewater treatment plants. Phosphorous in SSA is generally not plant available, and thus the SSA has no fertilizer value and thus the common practice is landfilling of the SSA. The natural deposits of phosphorous are rapidly depleting with the current consumption rate, and in such a speed that phosphorous already today is regarded as a scarce element. This is alarming as phosphorous is an irreplaceable element for all living organisms. Drivers to find appropriate applications for SSA instead of landfilling was initially to solve a waste problem due to increasing quantities of SSA [1-3] rather than the phosphorous reuse. Extensive research was carried out for the purpose of investigating possibilities to use SSA in production of construction materials in general and in cement based materials specifically [4-6]. Over the last decade, research on SSA utilisation has developed alongside the developments of waste management policy. The overall aim of the waste hierarchy in the European directive on waste [7] is to encourage EU member states to "reintroduce as much material as possible into production processes" [8]. By the introduction of the 
41 waste hierarchy, the conception of waste has also changed from the perception of waste as a problem to regarding waste as a resource [8]. This change is also reflected in studies on SSA utilisation, in which SSA is referred to as "secondary material” [6] and "useful material” [4]. When considering SSA as a resource, the main resource of interest in SSA is the relatively high content of phosphorous, which generally is $5-10 \mathrm{wt} \%$ [5].

In the Resource Strategy by the Danish Government in 2013, the target is to reuse $80 \%$ of phosphorous from sewage sludge (including SSA) by 2018. To reach this goal, efficient methods to recover the phosphorous from SSA are required and different methods are currently under development. The methods are grouped in two: thermochemical treatment or wet chemical extraction [4]. A drawback for the latter group is that in acid extraction, which is the method that achieves the highest percentage of phosphorus separation, the heavy metals are also extracted [9, 10], which hampers the use of the recovered phosphorous in fertilizer production. To obtain a clean phosphorous product, different processes for separation of phosphorous and heavy metals have been suggested, such as pH adjustment [11, 12], sulphide precipitation [11], cation exchange [9, 11] and electrodialytic separation $[13,14]$. The first three separation methods require a two-step treatment: first extraction then separation. In electrodialytic separation, the phosphorous extraction and heavy metal separation occur simultaneously.

Electrodialytic separation first developed for soil remediation, and was recently further developed for extraction of phosphorous from SSA with simultaneous heavy metal separation. Fig. 1 shows the patented two-compartment electrodialytic cell [15].

The anode is placed directly in a suspension of SSA and water. The cathode is placed in a separate compartment and a cation exchange membrane separates the two compartments. When a DC current is applied, the $\mathrm{pH}$ of the suspension decreases as protons are generated at the anode from 
electrolysis. Once $\mathrm{pH}$ reaches below 2, $\mathrm{P}$ and a part of the heavy metals are extracted. The heavy metal cations electromigrate to the catholyte passing the cation exchange membrane and thus the heavy metals are separated from the suspension, where phosphorus remains. Studies by Ebbers et al. [16] and Ottosen et al. [13] have shown that it is possible to recover more than $90 \% \mathrm{P}$ with this experimental set-up in laboratory scale (25-50 g SSA treated) and that the extracted phosphorous is pure from heavy metals and can be processed further to fertilizer [13].

A question now arises, whether the remaining mineral residue is an additional resource. A possible application for the SSA-ED could be as cement replacement in concrete. The $\mathrm{CO}_{2}$ emission from cement production is responsible for about $5 \%$ of the anthropogenic emission. Cement is the essential "glue" in concrete, and one way to lower the general $\mathrm{CO}_{2}$ emission related to concrete is to use materials with pozzolanic activity or filler effect as partly cement replacement. Research combining extraction of phosphorous and using the treated SSA as cement replacement is scarce. Donatello et al. [9] studied the use of sulfuric acid to recover phosphorous from SSA and use the acid washed SSA in mortar. They found that the sulphate from the acid influenced the properties of the mortars negatively compared to the untreated SSA. SSA-ED will not contain similar high sulphate content. The aim of the present work is to investigate the potential for combining electrodialytic extraction of phosphorous from SSA and the use SSA-ED as cement replacement in mortar.

\section{MATERIALS AND METHODS}

SSA from Avedøre, BIOFOS was used in the experiments, a wastewater treatment plant operating in the Copenhagen area, Denmark. The SSA was from mono-incineration of sewage sludge and it was sampled in May 2014. Iron salts were used at the wastewater treatment facility to precipitate P and the sewage sludge was incinerated in a fluidized bed combustor at about $850^{\circ} \mathrm{C}$. 


\section{Analytic procedures in ach characterization}

Characterization was made with dried ash and cement. Concentrations of $\mathrm{Cu}, \mathrm{Pb}, \mathrm{Zn}$ and $\mathrm{Cd}$ were measured with ICP-OES (Inductively Coupled Plasma - Optical Emission Spectrometry) after pretreatment in accordance to DS259: $1.0 \mathrm{~g}$ ash and $20.0 \mathrm{ml}(1: 1) \mathrm{HNO}_{3}$ was heated at $200 \mathrm{kPa}$ $\left(120^{\circ} \mathrm{C}\right)$ for 30 minutes and filtered through a $0.45 \mu \mathrm{m}$ filter prior to the analysis. Leaching experiments for $\mathrm{Cu}, \mathrm{Pb}, \mathrm{Zn}$ and $\mathrm{Cu}$ were made according to DS/EN 12457-3 part 1 at L/S 2, mixing $40 \mathrm{~g}$ material and $80 \mathrm{ml}$ distilled water for 24 hours. Ash $\mathrm{pH}$ and conductivity were measured by suspending $10.0 \mathrm{~g}$ ash in $25 \mathrm{ml}$ distilled water. After 1 hour agitation $\mathrm{pH}$ and conductivity were measured directly in the suspension with Radiometer electrodes. Water content was measured as weight loss after 24 hours at $105^{\circ} \mathrm{C}$ (calculated as weight loss over the weight of the wet sample). Loss on ignition (LoI) was found after 30 minutes at $550^{\circ} \mathrm{C}$ and additionally after 30 minutes at $950^{\circ} \mathrm{C}$. Five replicates of each of these analyses were made. Solubility in water was evaluated by suspending $50.0 \mathrm{~g}$ ash in $500 \mathrm{ml}$ distilled water and agitated for $1 \mathrm{~min}$, after settling the water was decanted and another $500 \mathrm{ml}$ distilled water added. This was repeated until the ash was washed three times. Finally, the suspension was filtered and the ash dried and weighed. Major oxide composition was estimated from semi-quantitative analysis by X-ray fluorescence (XRF) on powder samples by an external laboratory. The particle size distribution was measured by laser diffractometry. Ash mineralogy was studied by X-ray powder diffraction (XRD), for identification of major crystalline phases. The instrument was a PANalytical X'Pert Pro operating at $45 \mathrm{~mA}$ and $40 \mathrm{kV}$ applying $\mathrm{Cu} \mathrm{K} \alpha$ radiation with a $2 \Theta$ X'Celerator detector. The samples were scanned in the range of 4-100 $2 \Theta$ within 2.5 hours. The diffractograms were interpreted by using the ICDD PDF-4 database for minerals and the main peaks were identified.

\section{Electrodialytic bench-scale experiment}


Fig. 2 shows the ED bench-scale set up. It was built in a plastic container $(60 \times 40 \times 32 \mathrm{~cm})$. Two anodes were placed directly in the suspension. The cathodes were placed in cathode units, which were boxes with circulating catholyte. One side of the box (facing into the container) was a cation exchange membrane $\left(27 \times 37 \mathrm{~cm}^{2}\right)$ from Ionics. Both cathodes and anodes were platinum coated titanium meshes $\left(4 \times 20 \mathrm{~cm}^{2}\right)$.

The catholytes (25 l each) were prepared by mixing $21.5 \mathrm{~g}$ of $\mathrm{NaNO}_{3}$ with $50 \mathrm{ml}$ of $1: 1 \mathrm{HNO}_{3}$ into 251 of distilled water. Each of the two cathode units had a separate catholyte circulation system.

The SSA suspension prepared for the experiment had a liquid to solid (L:S) ratio of 10.3. First, 281 distilled water was added to the anolyte compartment. Thereafter $3 \mathrm{~kg}$ of SSA was mixed into $3 \mathrm{l}$ of distilled water in a separate tank and added gradually to the anolyte to make the full suspension. The SSA was kept suspended to avoid sedimentation in the container by three overhead stirrers (vos 14 /VWR).

A power supply (Blanko- Model Q J-3003C III) maintained a constant current. Each pair of electrodes shared the same power supply, however, independently connected to separate outlets. The duration of the experiment was 24 days and a constant current of 0.4 A was applied to each electrode pair for the first two days and 1.0 A for the remaining 22 days. The $\mathrm{pH}$ of the catholytes was adjusted with 1:1 $\mathrm{HNO}_{3}$ after 2, 4, 11 and 15 days, when the $\mathrm{pH}$ of the catholyte was above 2 . The $\mathrm{pH}$ and electrical conductivity (EC) were measured regularly in the SSA suspension at two places (named back and front, see Fig. 2). Samples of the SSA suspension were collected regularly, filtered, and the target elements were measured in the filtrate by ICP-OES.

After the ED experiment, the SSA suspension was filtered, dried at $50^{\circ} \mathrm{C}$ until the liquid had evaporated, crushed lightly by hand in a mortar, and finally stored in sealed plastic bags. Target elements, $\mathrm{pH}$ and conductivity were measured in the filtrate, SSA and catholyte at the end of the 
electrodialytic experiment. LoI, water content, water solubility, total and leaching concentrations of $\mathrm{Cd}, \mathrm{Cu}, \mathrm{Pb}$ and $\mathrm{Zn}$ (ICP-OES) and $\mathrm{P}(\mathrm{XRF})$ and mineralogy (XRD) were measured in the ED treated and dried ash.

\section{Mortar preparation and testing}

Before the SSA and SSA-ED (here refered to as test materials) were used in mortar, they were grinded for $0 \mathrm{sec}, 30 \mathrm{sec}$ and 10 min using a vibratory cup mill (FRITSCH - pulverisette 9). The grain size of the SSA and grinded samples are shown in Table 1. The grinded test materials were used for the production of test binders that consisted of $80 \%$ of cement and $20 \%$ either SSA or SSA-ED. In total mortar 8 mixes were produced (Table 2) The basic recipe, which was used for the mortar production, was $75 \%$ sand, $25 \%$ binder and a water/binder ratio of 0.5 . The sand was a coarse grained sea-sand $(0-4 \mathrm{~mm})$ and the cement used was CEM II/A-LL 52.5R. This particular type of cement has a reduced $\mathrm{CO}_{2}$ footprint compared with ordinary portland cement as up to $20 \%$ of the cement clinker is replaced by limestone filler.

The mortar was prepared in a Hobart mixer with the capacity of 5 liters. Binder (either cement or cement and SSA) was placed in the bowl, and the water was added. The mixer was switched on for $30 \mathrm{sec}$ at low speed. The sand was added during the next $30 \mathrm{sec}$, and then the mixer was switched to high speed and the mixing continued for another $30 \mathrm{sec}$. The mixer was stopped and the paste adhering to the inside of the bowl was within the next 30 sec removed by a scraper. After 60 sec of rest, the stirring process proceeded and the paste was stirred at high speed for another 60 sec.

The compaction procedure was executed by a vibrating table at a frequency of $53 \mathrm{~Hz}$. The mortar was placed in the mould within the first $30 \mathrm{sec}$ and the mortar was vibrated for another 90 sec. The mortar samples were sealed in plastic for 24 hours, demolded and cured in water vertically placed in a sealed plastic box. The two series were cured in separate boxes because the leaching of the 
mortars in the two series was expected to be different. M-SSA 0 sec -10 min were cured for 28 days and M-SSAED 0 sec -10 min for 40 days. The extended curing time applied for M-SSAED 0 sec -10 min may have influenced the compressive strength result. But because the strength increase levels out after 28 days, the two series, $\mathrm{M}-\mathrm{SSA}_{0 \mathrm{sec}-10 \mathrm{~min}}$ and $\mathrm{M}-\mathrm{SSAED}_{0 \mathrm{sec}-10 \mathrm{~min}}$, are roughly compared though taking the difference in the curing time applied into account.

Three prismatic specimens (160mm x 40mm x 40mm) were cast in each mould. After curing they were cut into 6 equal test samples $(80 \mathrm{~mm} \times 40 \mathrm{~mm} \times 40 \mathrm{~mm})$. For the determination of the compressive strength a Toni 3000 compression machine was used. The $\mathrm{pH}$ was measured and mineralogy investitaged on crused samples for the three different mortars.

The flow value expresses the workability of mortar with untreated and grinded SSA. Preparation of mortars followed DS/EN 191-3+A3 (DS 2009) and the tested mortars are those listed in Table 2. The flow value was determined according to DS/EN 1015-3 (DS 1999). A truncated conical mould (50 mm high, internal diameter $100 \mathrm{~mm}$ at the bottom and $70 \mathrm{~mm}$ at the top) was uniformly filled with mortar. The mould was removed, and the mortar exposed to jolting by slowly raising the mould $2 \mathrm{~cm}$ vertically and dropping it, 15 times at a rate of one pr. second at a flow table. The mean diameter $\left(\mathrm{d}_{\text {mean }}\right)$ from two measurements of the subsequent mortar diameter in two directions at right angles was found. The procedure was repeated twice for each mixture.

Metal leaching from mortars were made similarly as for the test mateirals accodring to DS/EN 12457-3 part 1 and the mortars were hand crushed prior to the mixing with distilled water. The buffering capacity of the mortars was determined according to Reddy et al. [17] by firstly preparing a suspension of the test material mixed in water $(6.7 \% \mathrm{w} / \mathrm{v})$ secondly stirring the suspension for 30 min before $\mathrm{pH}$ was measured. Successive $1 \mathrm{ml}$ of concentrated $\mathrm{HCl}$ were made every 30 min and pH was measured thereafter. This was repeated every 30 min until pH was below 2. 
179 For evaluation of the colour differences another type of samples were casted in moulds made from 180 film faced ply wood as desribed in detail in [18]. The dimensions of these moulds were

181 100x100x30mm. Paper cuttings were used to make both rough and smooth surfaces of the hardened 182 mortar, and a circular shape was cut out of the lining paper using a circle cutter. The paper was 183 moistened under running water for a few seconds. Before the frame was mounted, the wet paper 184 cutting was placed at the base of the mould and evened out with the means of a wall paper brush.

\section{RESULTS AND DISCUSSION}

186

\section{Phosphorous and heavy metals in the SSA before and after ED}

The investigated SSA contained 20.6 wt $\% \mathrm{P}_{2} \mathrm{O}_{5}$ (found from the XRF analysis), which corresponds to $9.0 \mathrm{wt} \% \mathrm{P}$ (Table 3). The $\mathrm{P}$ concentration in the investigated ash is slightly lower than in the previously investigated SSA batches from the same facility, 10wt\% [10], 12wt\% [16] and 11wt\% [13], however, the concentration is within the general range (5 - $10 \mathrm{wt} \% \mathrm{P}$ ) reported by Cyr et al. [5].

The initial SSA amount in the experiment was $3 \mathrm{~kg}$, and with a P concentration of $9 \mathrm{wt} \%$ the total mass of $\mathrm{P}$ was $270 \mathrm{~g}$. During ED, $\mathrm{P}$ was extracted from the SSA, and the concentration was decreased to about $1.0 \mathrm{wt} \% \mathrm{P}\left(2.3 \% \mathrm{P}_{2} \mathrm{O}_{5}\right)$ in SSA-ED. In ED lab scale experiments from [13] where successful P extraction was obtained from SSA from the same incineration plant, about 50\% SSA dissolved, and the same range of dissolution is expected in the present bench-scale experiment. Thus approximately $15 \mathrm{~g} \mathrm{P}$ was still bound in the SSA after ED, corresponding to 6\% of the total.

The concentration of $\mathrm{Cd}$ and $\mathrm{Cu}$ decreased in the SSA during ED (Table 4). The Cd concentration decreased from $2.8 \mathrm{mg} / \mathrm{kg}$ to $0.5 \mathrm{mg} / \mathrm{kg}$ (corresponding to $91 \%$ removal taking the $50 \%$ dissolution of SSA into account) and the Cu concentration decreased from $590 \mathrm{mg} / \mathrm{kg}$ to $460 \mathrm{mg} / \mathrm{kg}$ (61\% removal). This is on the contrary to the concentrations of $\mathrm{Pb}$ and $\mathrm{Zn}$, which both increased in the 
202 SSA during ED; Pb from 170 to $420 \mathrm{mg} / \mathrm{kg}$ and $\mathrm{Zn}$ from 2100 to $2600 \mathrm{mg} / \mathrm{kg}$. The reason for the 203 increased Zn concentration was that $38 \%$ Zn was removed, while the dissolution of SSA was $50 \%$. 204 The $\mathrm{Pb}$ removal was very limited. The increased $\mathrm{Pb}$ concentration in the SSA-ED cannot be 205 explained by dissolution alone. The Pb concentration of the initial SSA can vary greatly, which was 206 seen in another study on the similar SSA, where fifteen replicates of the untreated ash were 207 analyzed and a high variability of $\mathrm{Pb}$ was observed (208 $\pm 100 \mathrm{mg} / \mathrm{kg})$ [19]. Therefore, the $\mathrm{Pb}$ 208 removal cannot be sufficiently quantified. The $\mathrm{Cu}, \mathrm{Pb}$ and $\mathrm{Zn}$ mobilization in the present study was 209 significantly less than in the lab experiments with SSA from the same plant [13], where 85\% $\mathrm{Cu}$, $210 \quad 40 \% \mathrm{~Pb}$ and $77 \% \mathrm{Zn}$ were mobilized. 
215 As a constant current was applied to the electrodes during the ED experiment, the voltage varied as 216 a result of varying resistivity. The voltage generally decreased between both sets of electrodes, 217 from $30.8 \mathrm{~V}$ to about $10 \mathrm{~V}$ for Cat-An1 and $30.2 \mathrm{~V}$ to 10.8 for Cat-An 2, i.e. the voltage was in the 218 very same range in the two electrode sets. The $\mathrm{pH}$ decreased due to the electrolysis at the anodes, 219 and the conductivity of the SSA suspension did subsequently increase. Conductivity and $\mathrm{pH}$ in the 220 suspension during the experiment are shown in Fig. 3, and the measurements in the two sampling 221 points (back and front) are varying only very little at every time of analysis.

222 The experiment can be separated into four zones based on $\mathrm{pH}$ : (I) $\mathrm{pH}$ decreases from 7 to 3 during 223 over the first approximately 69 hours, (II) $\mathrm{pH}$ stabilizes between 2 and 3 until 356 hours, (III) pH 224 decreases gradually to 1 until about 475 hours (approximation as data points were not analysed 225 here), and (IV) pH stabilizes at 1 for the remaining hours of the experiment. The oxidation rate of $226 \mathrm{H}_{2} \mathrm{O}$ at the anode was constant (after 2 days) due to the constant current applied, and thus the rate of $227 \mathrm{H}^{+}$produced was constant. The $\mathrm{pH}$ in the suspension is buffered by the SSA in Zone II, and this 228 corresponds to the finding in [20], where a titration curve showed an ash buffering capacity around $229 \mathrm{pH}$ 2-3. In zone III, this buffering capacity was overcome, as $\mathrm{pH}$ decreases. In zone IV it is 230 expected that the current is nearly exclusively carried by $\mathrm{H}^{+}$ions, which at this point are present to a 231 very high extent in the suspension, and have a higher mobility than the other ions of the solution. 232 The conductivity of the suspension is almost linearly increasing over the duration of the experiment 233 irrespectively of $\mathrm{pH}$, showing the release of ions from the SSA during the buffering period in zone 234 II. 
The concentrations of $\mathrm{Cu}, \mathrm{Zn}$ and $\mathrm{P}$ in the filtrate of the SSA suspension during the ED experiments are shown in Fig. 4. Cu represents the heavy metals of which the concentration decreased in the SSA during the treatment and Zn the heavy metals for which the concentration increased.

An almost linear release of $\mathrm{P}$ over time is seen during the first two zones, where after the $\mathrm{P}$ concentration in the filtrate remains almost constant. Thus the P extraction was finished with Zone II, and the experiment could have been stopped here after about 360 hours. The P was thus extracted during the period, where the SSA had a buffering capacity around 2-3. It is commonly reported, that SSA contains whitlockite, e.g. [9]. Whitlockite is a group of structurally complex Cametal-phosphates, and as whitlockites are acid soluble, these minerals are dissolved during the ED treatment, and may contribute to the buffering capacity in Zone II; however, the large amorphous phase in SSA makes the pattern difficult to distinguish. The ED experiment could have been stopped at the end of zone II, as no more $\mathrm{P}$ was recovered after this period. The concentration of $\mathrm{P}$ was at this point about $8 \mathrm{~g} / \mathrm{l}$ in the filtrate and with approximately $31 \mathrm{l}$ filtrate this gives about $250 \mathrm{~g}$ P totally in the filtrate, which is by far the major part of the P initially in the ash (270 g).

The continuation of the experiment after the maximum extraction of P (zone II) with zone III and IV was not only an excessive use of energy, but it also decreased the quality of the filtrate as the $\mathrm{Zn}$ concentration increased (mainly in zone IV). The separation of heavy metals in this zone is not efficient as the $\mathrm{pH}$ is so low, that hydrogen ions will be by far the main charge carrier. Thus it is highly important to stop the ED process at the right time. At the end of zone II, the concentrations 254 of both $\mathrm{Cu}$ and $\mathrm{Zn}$ were about $10 \mathrm{mg} / \mathrm{l}$, which corresponds to $310 \mathrm{mg}$. Initially the $3 \mathrm{~kg}$ of ash 255 contained $1.8 \mathrm{~g} \mathrm{Cu}$ and $6.3 \mathrm{~g} \mathrm{Zn}$. Thus $18 \% \mathrm{Cu}$ and $5 \% \mathrm{Zn}$ was found in the filtrate.

\section{Characteristics of raw and treated ash}


Table 3 shows characteristics for the cement, SSA and SSA-ED. The requirements for use of coal fly ash (DS/EN 450-1:2007) in concrete are shown in the table for comparison, to evaluate the general quality of the SSAs. The $\mathrm{pH}$ of the SSA decreased from 9.3 to 3.5 during ED. The water solubility was low for both SSAs and should thus not lead to any volume changes when used in mortar. The LoI increase for the cement from $550^{\circ} \mathrm{C}$ to $950^{\circ} \mathrm{C}$ is due to the limestone filler in this type of cement and all LoIs met the requirements. The XRF analysis shown as oxide weight percentages in the materials (Table 3) showed that while the weight percentage of $\mathrm{Fe}_{2} \mathrm{O}_{3}$ increases the weight percentage of $\mathrm{Al}_{2} \mathrm{O}_{3}$ decreases during ED. The weight percentage of $\mathrm{SiO}_{2}$ increases, showing that Si was mainly present in the part of the SSA, which was not dissolved during ED. In SSA-ED the weight percentages of $\mathrm{Al}_{2} \mathrm{O}_{3}, \mathrm{Fe}_{2} \mathrm{O}_{3}$ and $\mathrm{SiO}_{2}$ summed up to $73 \%$ of the mass, whereas in the SSA the sum of these major oxides was $43 \%$. Comparing these weight percentages to the requirements for coal fly ash used in concrete it was seen that the ED treatment made the SSA more eligible for use in concrete. Also the reduction in $\mathrm{SO}_{3}$ due to the $\mathrm{ED}$ treatment is favourable for the SSA as material. The content of $\mathrm{CaO}$ was also greatly reduced in the SSA-ED, which can be linked to the lower $\mathrm{pH}$ and that Ca-containing minerals and phases will dissolve at acidic $\mathrm{pH}$. This will also mean that the buffer capacity of the SSA-ED has been reduced and this together with the acidic $\mathrm{pH}$ could negatively influence the properties of the mortar when used as substitution for cement.

The heavy metal content and leaching for the cement and SSAs are seen in Table 4 and the concentrations are compared to limit values for reuse of non-hazardous materials for geotechnical purposes [21], as there are no limits for reuse in construction materials. Both the leaching results in this study and the limit values [21] are based on the DS/EN 12457-3 part 1 leaching test. The leaching concentrations of $\mathrm{Cu}, \mathrm{Pb}$ and $\mathrm{Zn}$ in the SSA-ED exceeded these limits, mostly because the SSA after electrodialytic treatment is acidic. The leaching from SSA-ED was $14 \% \mathrm{Cd}, 4 \% \mathrm{Cu}$ and $\mathrm{Zn}$ and $0.04 \% \mathrm{~Pb}$ compared to the total concentrations in this ash. 
282 There were no similarities in the mineralogy between cement and the SSA samples, as seen in Fig.

283 5. The cement consisted, as expected, of the main cement minerals $\mathrm{C}_{3} \mathrm{~S}$ (alite), $\mathrm{C}_{2} \mathrm{~S}$ (belite) and $284 \mathrm{C}_{4} \mathrm{AF}$ (ferrite). Celite $\left(\mathrm{C}_{3} \mathrm{~A}\right)$ was not detected in the diffractogram, which could be due to peak 285 overlap, having the main peak at $33.15\left({ }^{\circ} 2 \theta\right)$ and ferrite with major peaks at $33.53\left({ }^{\circ} 2 \theta\right)$ and 33.92 286 ( $\left.{ }^{\circ} 2 \Theta\right)$. Rietveld analysis on Portland cement has previously shown $6.5 \% \mathrm{C}_{3} \mathrm{~A}$ compared to $63.6 \%$ $\mathrm{C}_{3} \mathrm{~S}, 8.9 \% \mathrm{C}_{2} \mathrm{~S}$ and $14.2 \% \mathrm{C}_{4} \mathrm{AF}$ [22]. Anhydrite $\left(\mathrm{CaSO}_{4}\right)$ was also found in the present cement. 288 The main difference between the raw and ED treated SSA, was the removal of calcium phosphate in 289 the ED treated ash, which could be expected due to the overall P removal (Table 3). Otherwise SSA 290 and SSA-ED were mineralogically consisting mainly of Q (quartz), Fe (feldspar) and H (hematite).

The XRD diffractograms for the three different mortars (M-ref, M-SSA and M-SSA-ED the two latter with non-grinded SSA) are seen in Fig. 6. The main mineralogical phases in the mortars were similar regardless of the substitution of cement with SSA. Quartz $\left(\mathrm{SiO}_{2}\right)$, the plagioclase feldspars 295 albite $\left(\mathrm{NaAlSi}_{3} \mathrm{O}_{8}\right)$ and $\mathrm{K}$-spar $\left(\mathrm{KAlSi}_{3} \mathrm{O}_{8}\right)$, calcite $\left(\mathrm{CaCO}_{3}\right)$ and the hydration product portlandite $\left(\mathrm{Ca}(\mathrm{OH})_{2}\right)$ were the main identified minerals. The mortar diffractograms did not show calcium phosphate or hematite which was present in the SSAs (Fig. 5). This is likely due to the dominating minerals from the sand, the cement hydration and the dilution effect since SSA only replaced $20 \%$ of the cement. At the same time, the quartz and feldspar in the SSAs were additionally contributing to the quartz and feldspars present in the mortar sand, these two minerals which are the most common minerals in sand from Danish sand pits [23], thus, this is coherent with finding these as the main minerals in the mortars. 
Incorporation of ED treated MSWI fly ashes with high leaching concentrations in mortars have shown comparable leaching levels to a reference mortar for $\mathrm{Cd}, \mathrm{Cu}, \mathrm{Pb}$ and $\mathrm{Zn}$, probably because the metals were incorporated in the alkaline mortar matrix [24]. The leaching of the SSA-ED containing mortars is shown in Table 5 and gives an indication of the worst case environmental impact when replacing cement with SSA compared to Danish regulation for the maximum leaching concentrations for disposing inert and mineral waste [25]. The leaching of $\mathrm{Cd}$ and $\mathrm{Pb}$ from all mortars was below $20 \mu \mathrm{g} / \mathrm{l}$ and only leaching of $\mathrm{Cu}$ and $\mathrm{Zn}$ from the mortars containing SSA could be detected. For the M-SSA-ED, the leaching was reduced when the SSA was grinded, indicating a better incorporation of the heavy metals in the mortar matrix. Compared to the limit values, the leaching was below the values for inert and mineral waste, waste which is considered to undergo no or limited chemical reactions in contact with water, respectively.

The $\mathrm{pH}$ for all the mortars was 12.3, which shows that the acidic electrodialytic treated SSA did not significantly affect the $\mathrm{pH}$ of the mortar on a short term basis. However, as can be seen from the buffering capacity of the mortars (Fig. 7), the mortar containing SSA-ED is less resistant towards acidification compared to the SSA-received and the reference mortars. This could influence the long term leaching from the mortars due to the weathering processes of mortar in-situ and the subsequent decrease in mortar $\mathrm{pH}$.

The compressive strength was slightly lower when the mortars contained SSA as well as SSA-ED compared to the reference mortar (Fig. 8a), but the SSA-ED still gave compressive strengths above $50 \mathrm{MPa}$ for all tested mortars, which is sufficient for most uses of concrete. For the mortar with SSA, the compressive strength increased in accordance to an increase in the fineness of the SSA particles (Fig. 8b). This finding corresponds to results reported in the studies of Pan et al., and Donatello et al. [9, 26]. In these two studies, it was found that the specific surface area did not increase significantly even though the fineness of the particles did due to the grinding. Therefore, it 
was suggested that the SSA particles had a porous structure with many open pores, adding to the overall specific surface area. As consequence of the high open porosity, the available water in the system was reduced, which could have inhibited the hydration process of the clinker minerals [9] as well as the workability of the mortars [26]. The improved compressive strength (Fig. 8) and workability (Fig. 9) found for M- SSA 30 sec and M-SSA $A_{10 m i n}$ supports this assumption. Furthermore, the fineness of a pozzolanic material is important for the hydration process, because fine particles provide extra nucleation sites due to large surface areas and at the same time extra space in the system for hydration products to form and develop at the early stage [27]. In case the fine particles are without pozzolanic activity, they may improve the strength from a filler effect.

Even though the d50 were quite similar for SSA and SSA-ED (Table 1) the graduation differs. The d10 was $14 \mu \mathrm{m}$ for SSA and $3 \mu \mathrm{m}$ for SSA-ED, and thus SSA-ED had the largest fraction of the finest particles. At the same time, SSA-ED also had the largest fraction of the coarsest particles, as d90 was $817 \mu \mathrm{m}$ compared to $356 \mu \mathrm{m}$ for the SSA. Thus, the grain sizes differed more in SSA-ED than in SSA. After grinding SSA-ED for 30 sec the d90 is still coarser than in the SSA. The increased concentration of Si (Table 3) in SSA-ED, of which a large fraction is present in quartz (Fig. 5) may be related to this. The quartz may originate from the sand in the fluidized bed, i.e. relatively coarse particles, and quartz is not easily grinded to finer particle sizes. Still after $10 \mathrm{~min}$ grinding, the SSA-ED has larger d90 than SSA. The increase in compressive strength with

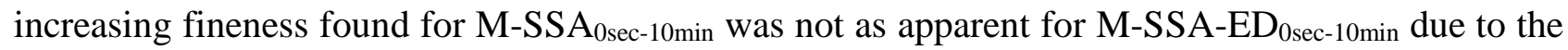
larger particle sizes (Fig. 8b). The compressive strength increased from 51 MPa to $55 \mathrm{MPa}$ when grinding the SSA-ED for $30 \mathrm{sec}$, but the longer grinding (finer particles) did not give further strength increase. This reveals that the grain size graduation obtained with the longer grinding did not improve the packing of particles. 
The workability expressed by flow value spread (Fig. 9) was lower for all mortars with SSA and SSA-ED than for the flow value of the reference mortar. The lower workability was also experienced during the mortar mixing where the test mortars were dryer. Increased fineness is generally expected to improve the workability, which was also seen here for the SSA with the grinding time of 10 minutes. The flow value for mortar with grinded SSA increased as expected but smaller particle sizes of SSA-ED 30 sec -10min had no influence on the flow value and did not improve the workability of M-SSAED 30 sec-10min.

An irregular morphology of SSA particles is likely adding to a lower workability [28] as well as the porous structure of SSA particles must be expected to influence the workability negatively, in that the pores absorbs water from the mixture $[9,26]$.

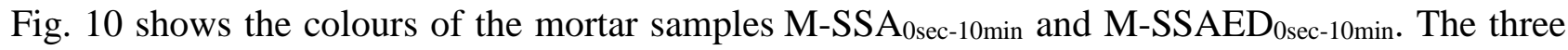
mortars with SSA-ED $\mathrm{Esec}_{10 \mathrm{~min}}$ all had a more intense red colour than the mortars with $\mathrm{SSA}_{0 \text { sec-10min }}$. The colour originates from the hematite $\left(\mathrm{Fe}_{2} \mathrm{O}_{3}\right.$, see Fig. 5), and the concentration of Fe was higher in SSA-ED than SSA (Table 3). The saturated red colour was similar for all three samples with SSA-ED 0 sec-10min whereas the colours of M-SSA 0 sec-10min evolved slightly in the intensity as the particle size of the SSA decreased. Grinding the ash means larger surface area, which results in the slightly stronger colour of the grinded mortars with SSA. Thus, the colours of M-SSA 0 sec-10min were induced by the physical changes of the SSA whereas the colours of M-SSAED 0 sec-10min most likely were due to the chemical changes of SSA-ED. It is possible that a very low content of CaO together with a higher content of Fe for SSA-ED (Table 3) may have caused the significant colour change of M-SSAED 0sec-10min $_{\text {compared to faint colours of M-SSA }}$ sec-10min. It is known from the composition of minerals in clay that a high content of Fe together with a low content of $\mathrm{CaO}$ generates the red colour known in bricks [29]. The rough and smooth surfaces made by the paper cuttings were made to unfold the aesthetical qualities of the mortar. The rough and smooth surfaces are basic elements 
of architecture and therefore important for architects and to experience architecture awareness of these elements are necessary [30]. The difference between the smooth parts which are the spherical part of the samples in Fig. 9 and the rough part, accentuate the colours of the mortars. From Fig. 9 it can be seen that the visual difference in the colour tones between rough and smooth parts are clearer for the samples with SSA than for samples with SSAED. The colours of M-SSAED 0 sec-10min may be conceived as an intrinsic property of the material which aesthetically can be used in the build environment for exposed concrete structures.

\section{CONCLUSION}

- Electrodialytic separation extracted $90 \%$ of phosphorous from the SSA. The electrodialytic treatment reduced the $\mathrm{pH}$ of the SSA from 9.3 to 3.5, however, no immediate influence of the acidic $\mathrm{pH}$ of the ash were seen from the results of the mortar testing. The acidic $\mathrm{pH}$ though increased the heavy metal leaching of the electrodialytically treated SSA and the leaching properties should be studied further for the mortars containing the SSA.

- Compressive strengths over $50 \mathrm{MPa}$ were achieved for mortars with grinded SSA, although the compressive strength decreased when replacing cement with SSA compared to the reference (60 MPa). Grinding the SSA increased the compressive strengths for both SSAs, from 43 to $58 \mathrm{MPa}$ for the as received SSA and from 51 to $55 \mathrm{MPa}$ for the electrodialytically treated SSA.

- The fineness and mineralogy of the SSA changed due to the electrodialytic treatment, probably influenced by the dissolution of the ash constituents at the acidic $\mathrm{pH}$.

- The red color intensified in the mortar with SSA-ED compared to the SSA, into a color similar to red bricks. The red color was homogeneous in the entire mortar sample and on 
both the smooth and rough surfaces. The study showed that electrodialytic treated SSA may have potentials to be utilized as resource in cement based materials especially in places where the colour aesthetically can add value to the build environment.

\section{Acknowledgements}

Laboratory technician Ebba Cederberg Schnell is thanked for the analytical work with the SSA samples.

\section{References}

[1] Tay, J.: Sludge Ash as Filler for Portland Cement Concrete. J. Environ. Eng. 113(2), 345-351 (1987)

[2] Bhatty, J. I., Reid, K. J.: Compressive Strength of Municipal Sludge Ash Mortars. ACI Materials (1989)

[3] Pinarli, V., Kaymal, G.: An innovative sludge disposal option - Reuse of sludge ash by incorporation in construction materials. Environ. Technol. 15, 843-852 (1994)

[4] Donatello, S., Cheeseman, C. R.: Recycling and recovery routes for incinerated sewage sludge ash (ISSA): A review. Waste Manage. 33(11), 2328-2340, (2013)

[5] Cyr, M., Coutand, M., Clastres, P.: Technological and environmental behavior of sewage sludge ash (SSA) in cement-based materials. Cement Concrete Research 37(8), 1278-1289 (2007)

[6] Lynn, C. J., Dhir, R. K., Ghataora, G. S., West, R. P.: Sewage sludge ash characteristics and 
[7] EC. Directive 2008/98/EC on waste: EUR-Lex - 32008L0098 - EN (2008). European 423 Commission.

[8] Hultman, J., Corvellec, H.: The European Waste Hierarchy: from the sociomateriality of waste

[9] Donatello, S., Freeman-Pask, A., Tyrer, M., Cheeseman, C. R.: Effect of milling and acid washing on the pozzolanic activity of incinerator sewage sludge ash. Cement Concrete Composites 430 32(1), 54-61 (2010)

431

[10] Ottosen, L.M., Kirkelund, G.M., Jensen, P.E.: Extracting phosphorous from incinerated sewage sludge ash rich in iron or aluminium. Chemosphere 91, 963-969 (2013)

[11] Franz, M.: Phosphate fertilizer from sewage sludge ash (SSA). Waste Manage. 28, 1809 1818 (2008)

[12] Takahashi, M.; Kato, S., Shima, H., Sarai, E., Ichioka, T., Hatyakawa, S.,Miyajiri, H.: 439 Technology for recovering phosphorus from incinerated wastewater treatment sludge. Chemosphere 440 44, 23-29 (2001) 
444 [14] Guedes, P., Couto, N., Ottosen, L. M., Ribeiro, A.B..Phosphorus recovery from sewage sludge 445 ash through an electrodialytic process. Waste Manage. 34 (5) 886-892 (2014)

446 [15] Ottosen, L.M., Jensen, P.E., Kirkelund, G.M., Ebbers: B.E: Electrodialytic separation of heavy 447 metals from particulate material. Patent WO2015032903-A1

448

449 [16] Ebbers, B., Ottosen, L. M., Jensen, P. E.: Comparison of two different electrodialytic cells for 450 separation of phosphorus and heavy metals from sewage sludge ash. Chemosphere 125, 122-129 $451 \quad(2015)$

453 [17] Reddy, K.R, Donahue, M., Saichek, R.E., Sasaoka, R.: Preliminary Assessment of 454 Electrokinetic Remediation of Soil and Sludge Contaminated with Mixed Waste. J. Air Waste 455 Manage. Assoc. 49, 823-830 (1999).

457 [18] Kappel, A., Ottosen, L. M., Kirkelund, G. M., Bache, A. M., Goltermann, P.: The colour 458 potentials of SSA-containing mortar. Fib Symposium Proceedings: Concrete - Innovation and 459 Design. ed. / H. Stang; M. Bræstrup (2015)

460

461 [19] Parés Viader, R., Jensen, P. E., Ottosen, L. M., Thomsen, T. P., Ahrenfeldt, J., Hauggaard462 Nielsen, H.: Comparison of phosphorus recovery from incineration and gasification sewage sludge 463 ash. Water Sci. Technol., 75(5), 1251-1260 (2017) 
465 [20] Kappel, A., Ottosen, L.M., Kirkelund, G.M.: Colour, compressive strength and workability of 466 mortars with an iron rich sewage sludge ash. Construction Building Materials 157, 1199-1205 $467 \quad(2017)$

468

469 [21] Miljø -og Fødevareministeriet, Miljøstyrelsen (Danish EPA) (2015) Announcement for 470 recycling of residues and soil for building and construction BEK nr 1414 af 30/11/2015 (in Danish). 471

472 [22] Snellings, R., Salze, A., Scrivener, K.L.: Use of X-ray diffraction to quantify amorphous 473 supplementary cementitious materials in anhydrous and hydrated blended cements. Cement 474 Concrete Research 64, 89-98 (2014)

475

476 [23] Dam, H.C., Gerward, L., Leistiko, O., Lindemark, T, Nielsen, A., Sørensen, O.T.: 477 Materialebogen. Nyt Teknisk Forlag, København, Denmark. (2008)

478

479 [24] Magro, C. C., Guedes, P. R., Kirkelund, G. M., Jensen, P. E.., Ottosen, L. M., Ribeiro, A. B.: 480 Incorporation of Different Fly Ashes from MSWI as Substitute for Cement in Mortar : An 481 Overview of the Suitability of Electrodialytic Pre-treatment. In: Electrokinetics Across Disciplines 482 and Continents: New Strategies for Sustainable Development, pp. 225-247. Springer, Heidelberg 483 (2016)

484

485 [25] Danish Ministry of the Environment, “Bekendtgørelse deponeringsanlæg”, BEK nr 719 af 486 24/06/2011, 2011. (In Danish).

488 [26] Pan, S.-C., Tseng, D.-H., Lee, C.-C., Lee, C.: Influence of the fineness of sewage sludge ash 
489 on the mortar properties. Cement Concrete Research 33 (11), 1749-1754 (2003)

490

491 [27] Lothenbach, B., Scrivener, K., Hooton, R.D.: Supplementary cementitious materials. Cement 492 Concrete Research 41(12), 1244-1256 (2011)

493

494 [28] Monzó, J.; Payá, J.; Borrachero, M.V.; Girbé, I.: Reuse of sewage sludge ashes (SSA) in 495 cement mixtures: the effect of SSA on the workability of cement mortars. Waste Manage. 23, 373$496381(2003)$

497

498 [29] Linnet, E.: Keramikernøglen. Gad, København (1996)

499

500 [30] Rasmussen, S.E.: Experiencing architecture. M.I.T. Press (1962)

501 


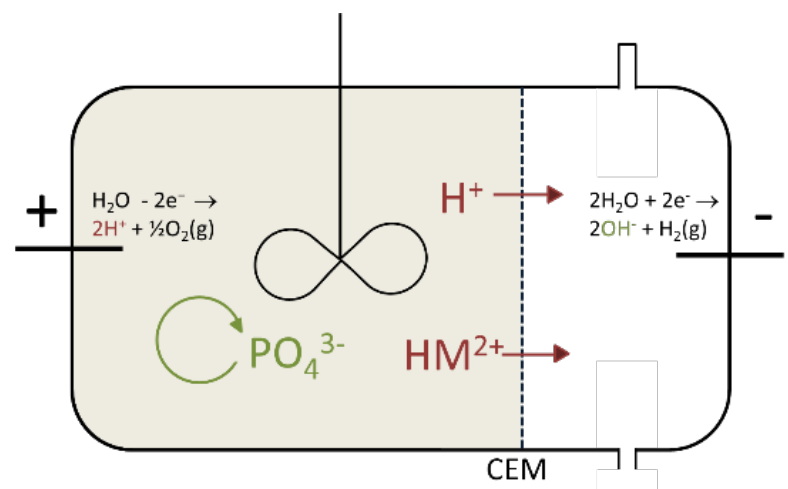

Fig. 1 The two compartment electrodialytic set-up for treating a material suspension. CEM-cation exchange membrane, $\mathrm{HM}^{2+}$ - heavy metal cation 


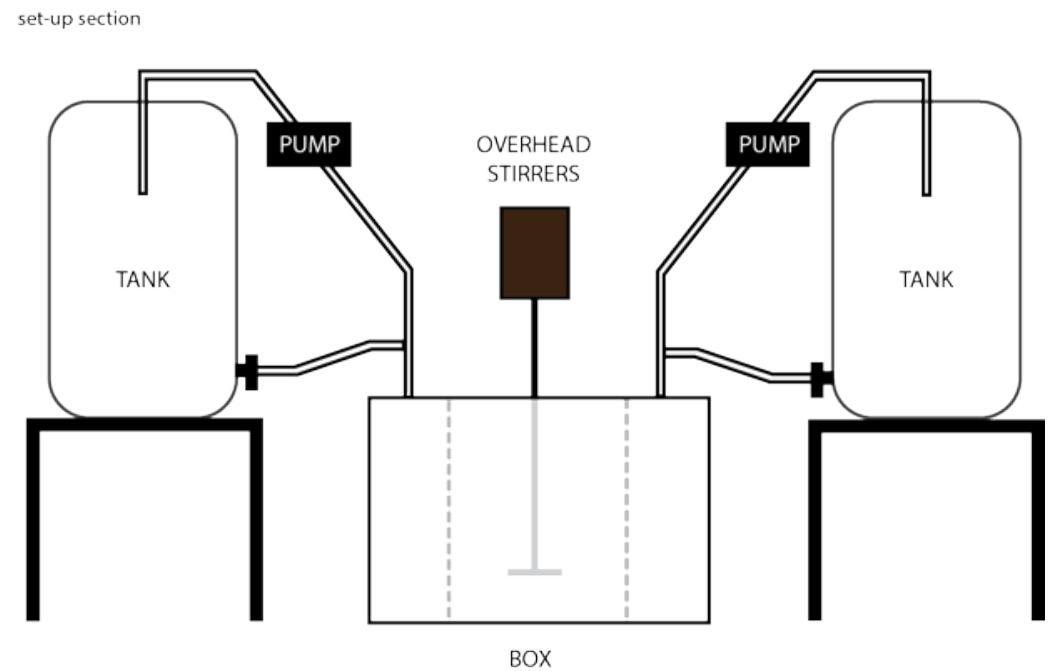

flow diagram top view
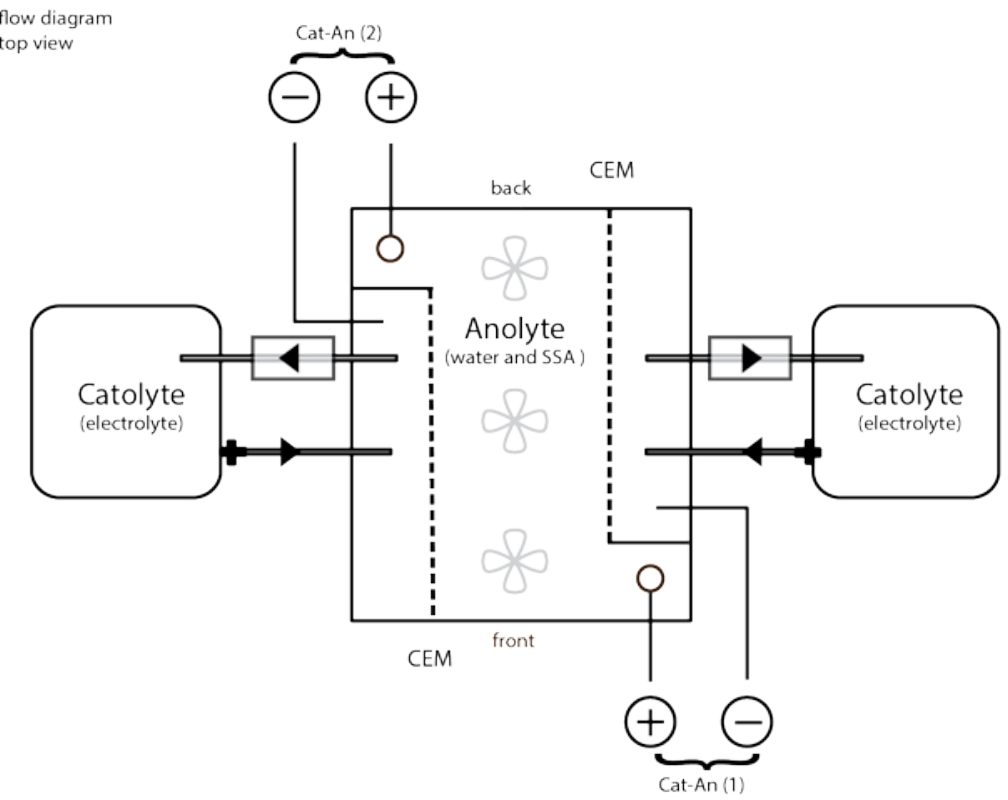

Fig. 2 The bench scale electrodialytic experimental setup, CEM-cation exchange membrane 


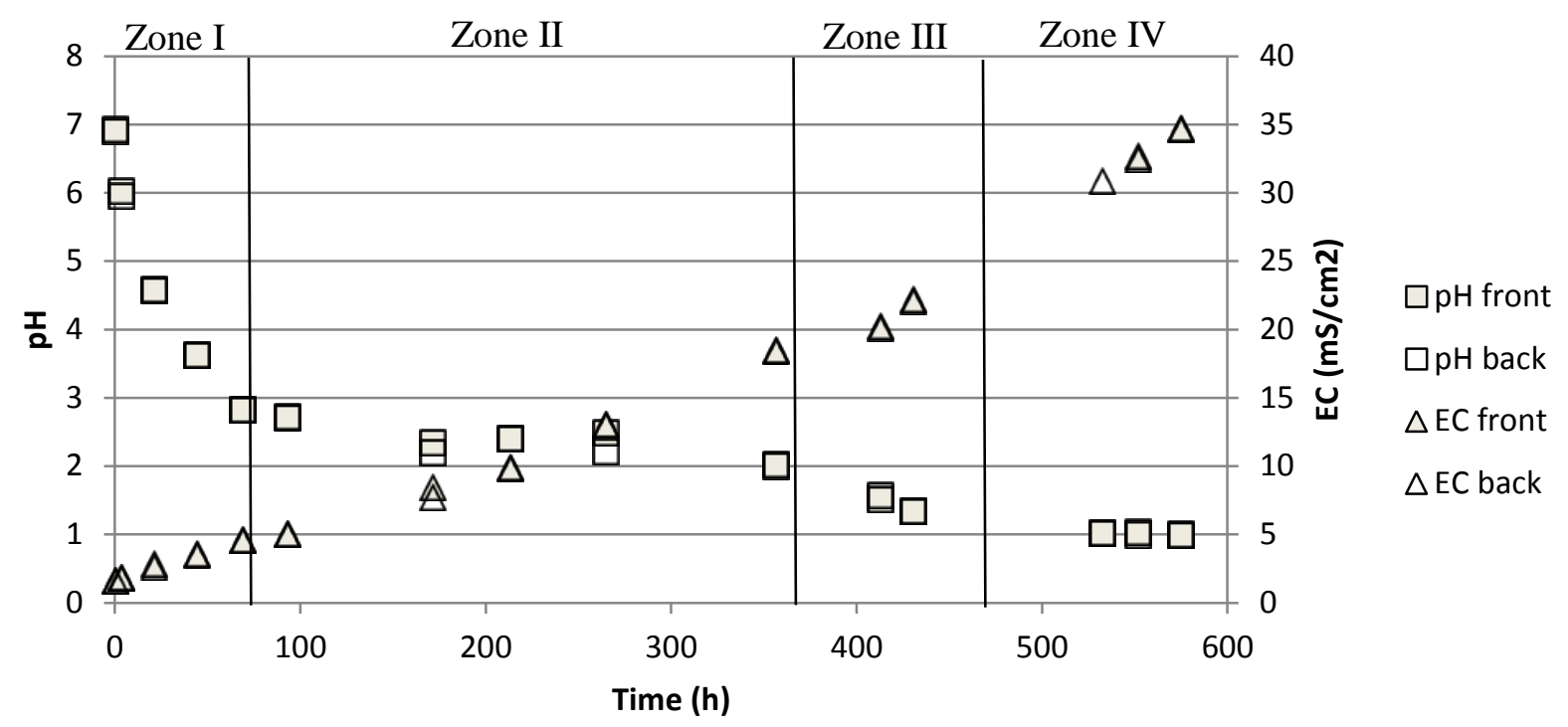

Fig. $3 \mathrm{pH}$ and conductivity on the SSA suspension during the ED experiment 


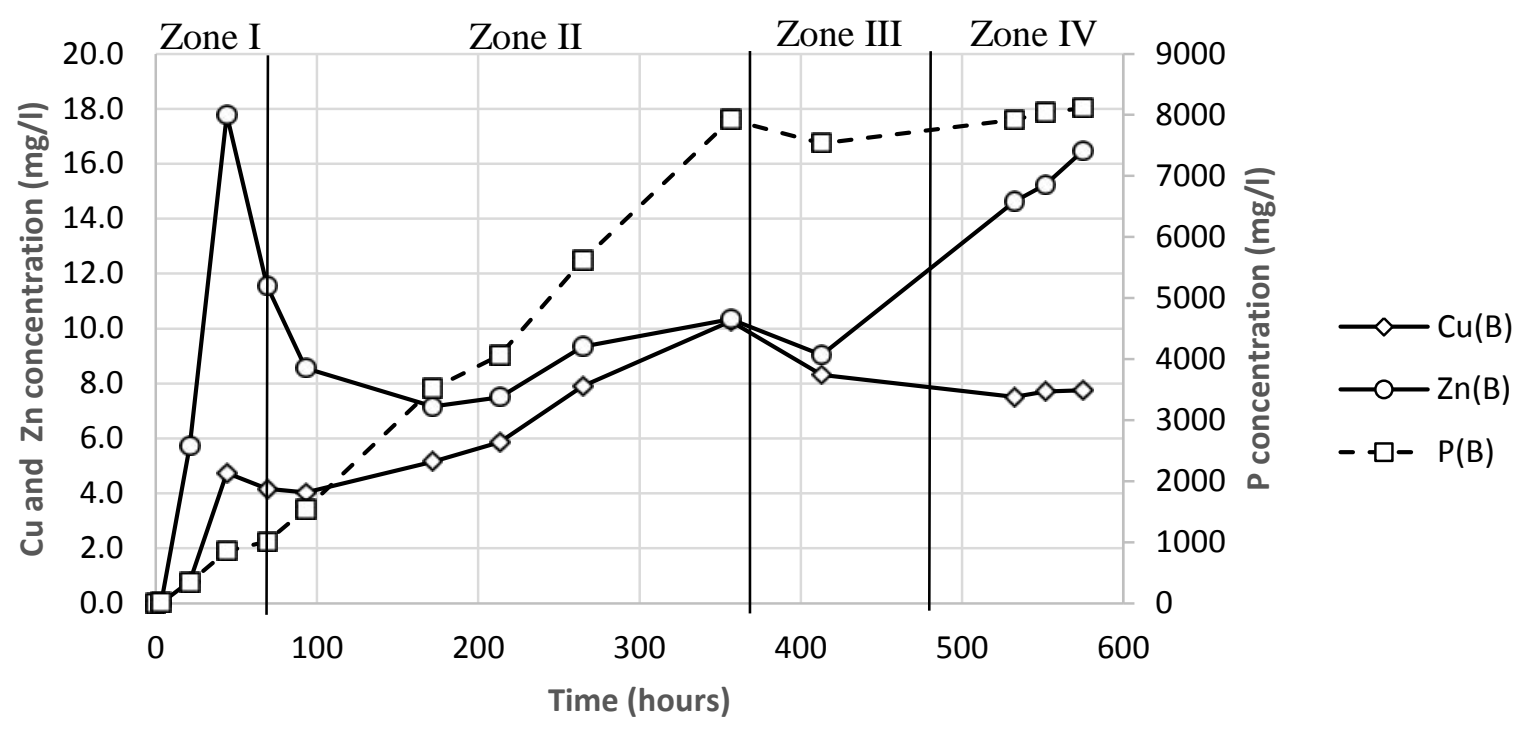

Fig. 4 Concentration of $\mathrm{Cu}, \mathrm{Zn}$ and $\mathrm{P}$ during ED in the liquid of the SSA suspension. The horizontal lines corresponds to the zones in acidification (Fig. 3) 


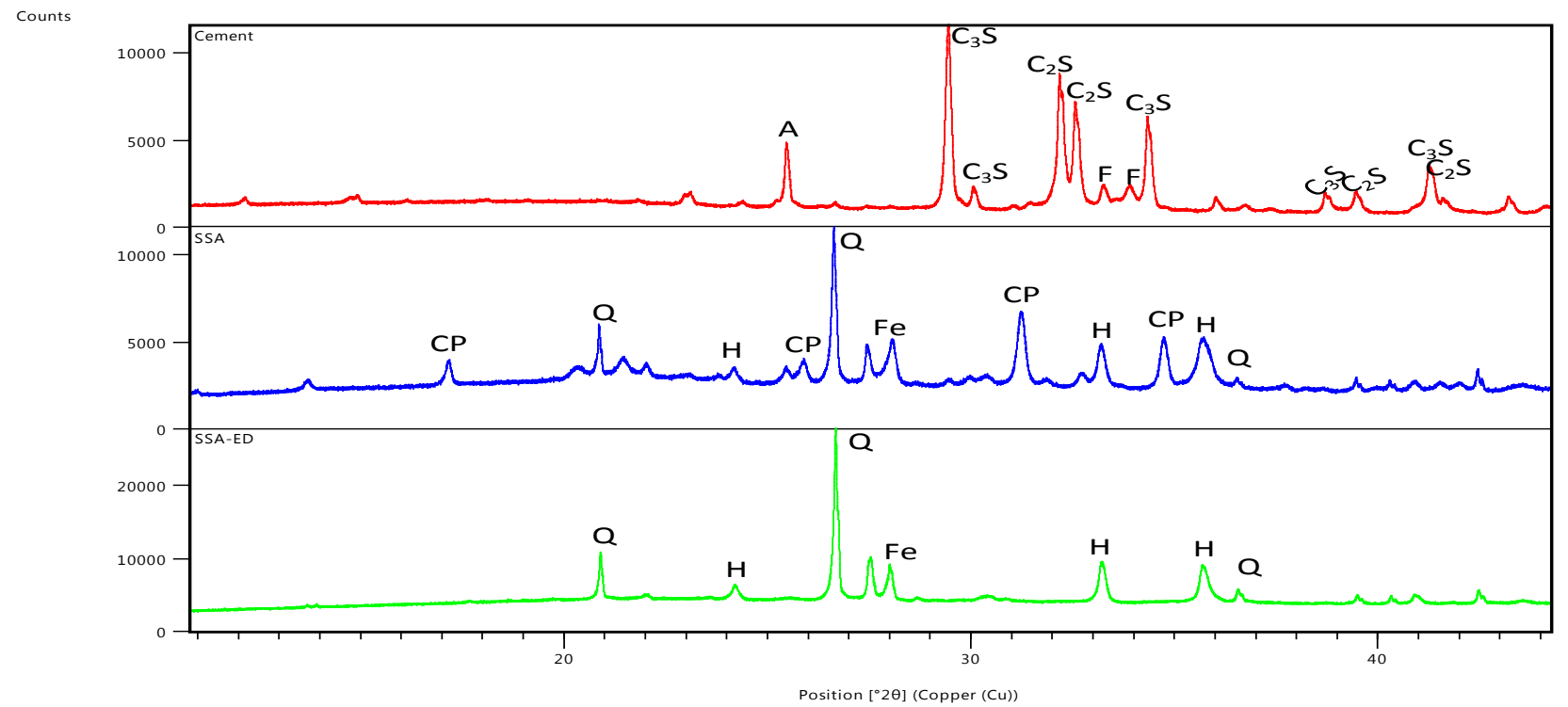

Fig. 5 XRD diffractograms for cement and SSA samples A- anhydrite, Q - quartz, H- hematite, CPcalcium phosphate, $\mathrm{Fe}$ - feldspar, $\mathrm{C}_{3} \mathrm{~S}$ - alite, $\mathrm{C}_{2} \mathrm{~S}$ - belite, $\mathrm{F}$ - ferrite 


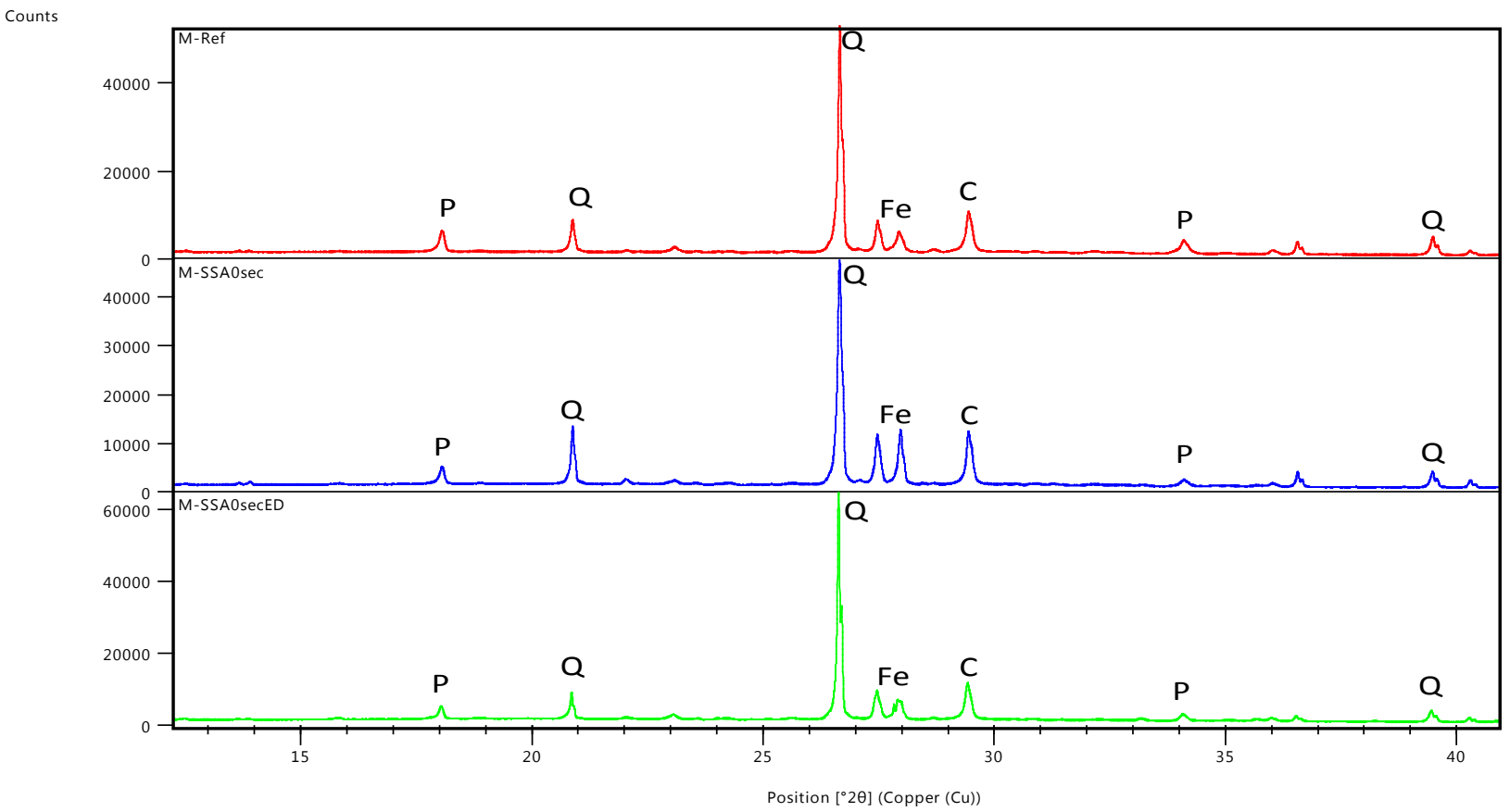

Fig. 6 XRD diffractograms for mortar samples. P- portlandite, Q-quartz, C, calcite, Fe - feldspar 


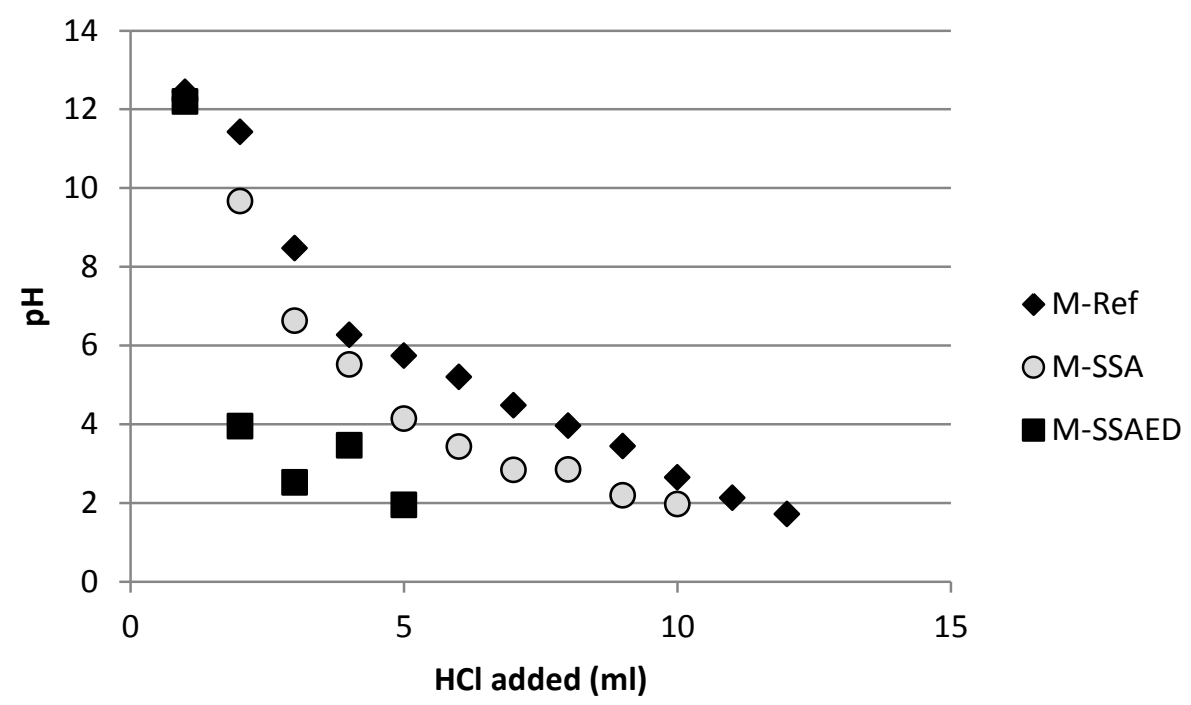

Fig.7 Buffering capacity to test mortars 

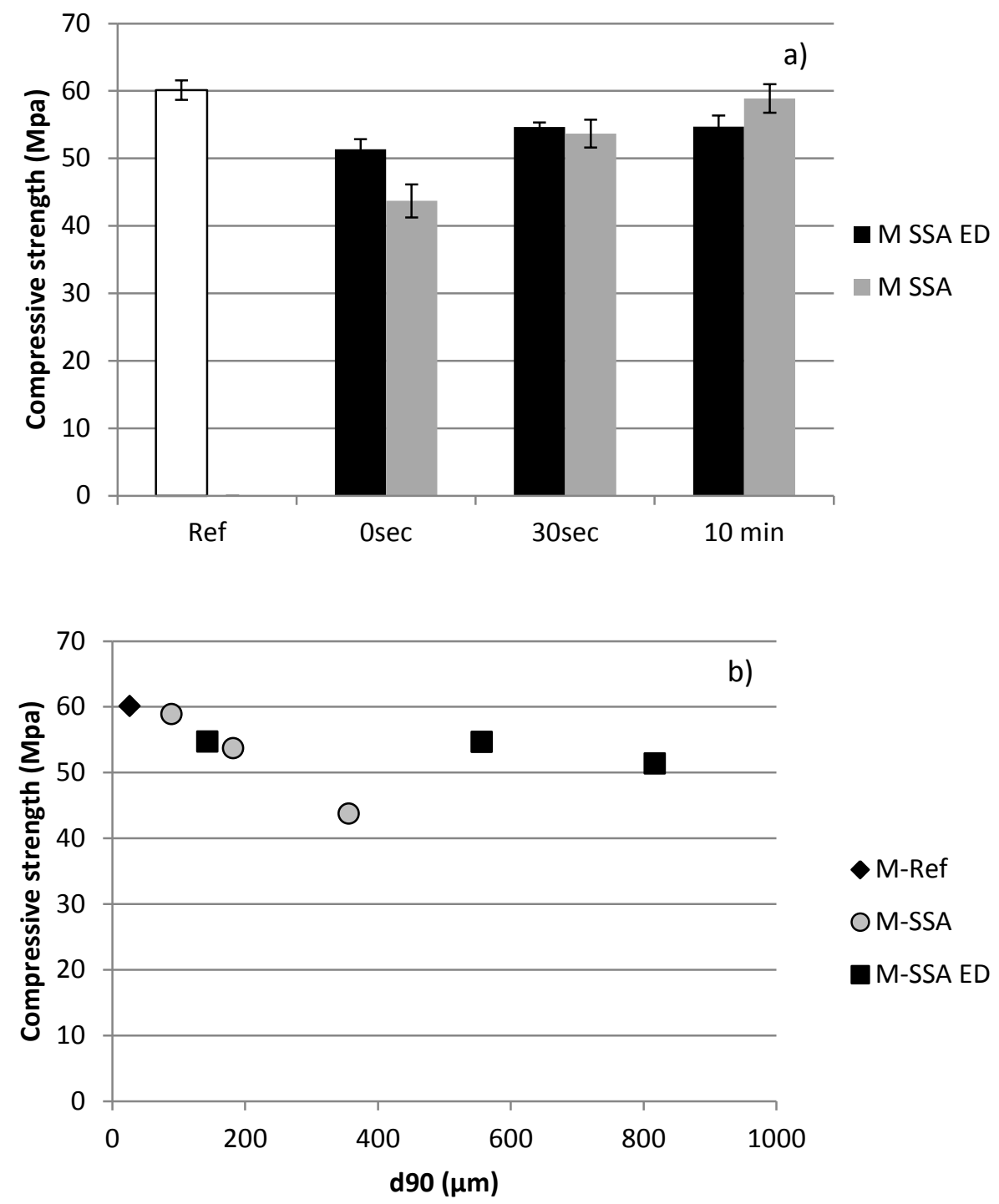

Fig. 8 Compressive strength of the mortars by a) grinding time and b) d90 in the SSA 


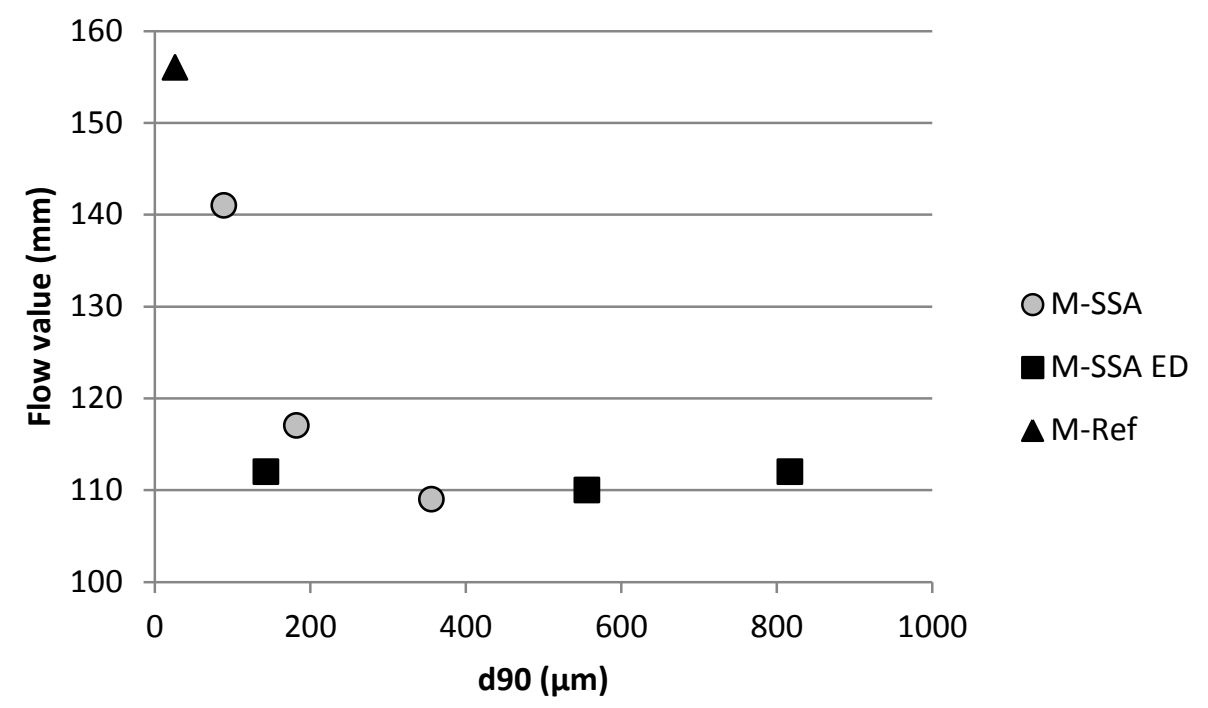

Fig. 9 Workability of the mortars expressed by the flow value spread. The d90 value is for the SSA part of the SSA mortars and for the cement in the reference mortar 


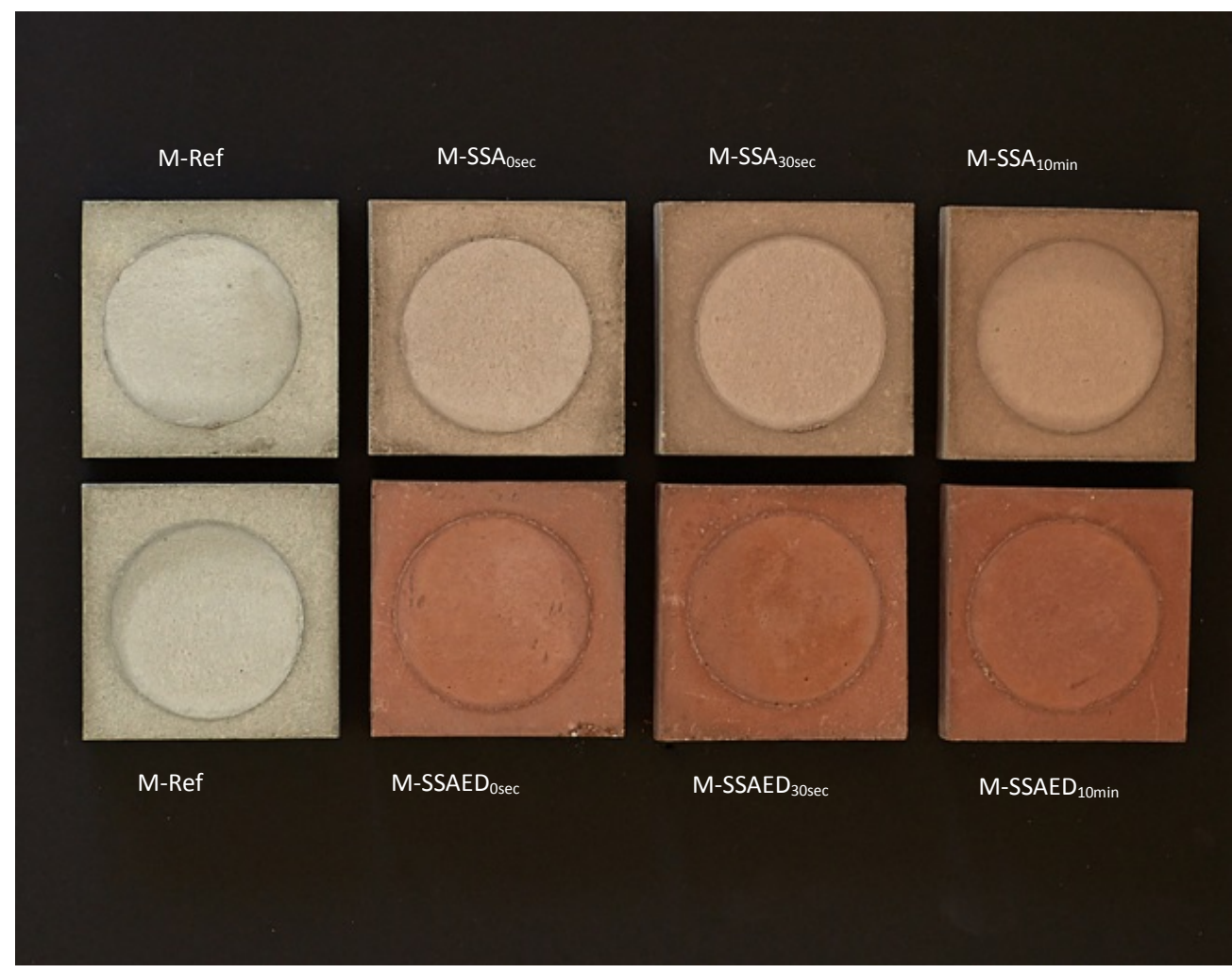

Fig. 10 Colours of the experimental mortars 
Table 1 Grain distribution of the tested materials

\begin{tabular}{llll}
\hline & $\mathrm{d} 10(\mu \mathrm{m})$ & $\mathrm{d} 50(\mu \mathrm{m})$ & $\mathrm{d} 90(\mu \mathrm{m})$ \\
\hline Cement & 1.72 & 8.45 & 26.2 \\
SSA $_{\text {0sec }}$ & 14.1 & 124 & 356 \\
SSA $_{30 \text { sec }}$ & 5.59 & 39.8 & 182 \\
SSA $_{10 \mathrm{~min}}$ & 3.54 & 24.1 & 89.0 \\
SSA-ED $_{\text {SSA-ED }}$ & 2.79 & 101 & 817 \\
SSA $_{\text {sec }}$ & 2.22 & 44.1 & 556 \\
\hline
\end{tabular}


Table 2 Recipes of the mortars. * indicating either SSA or SSA-ED

\begin{tabular}{llllll}
\hline Labelling & Ash* & $\begin{array}{l}\text { Grinding } \\
\text { interval }\end{array}$ & Cement & Sand & Water \\
\hline M -Ref & $\div$ & $\div$ & $450 \mathrm{~g}$ & $1350 \mathrm{~g}$ & $225 \mathrm{~g}$ \\
$\left.\mathrm{M}-(\ldots)^{*}\right)_{0 \mathrm{sec}}$ & $90 \mathrm{~g}$ & $0 \mathrm{sec}$ & $360 \mathrm{~g}$ & $1350 \mathrm{~g}$ & $225 \mathrm{~g}$ \\
$\mathrm{M}-(\ldots)_{30 \mathrm{sec}}$ & $90 \mathrm{~g}$ & $30 \mathrm{sec}$ & $360 \mathrm{~g}$ & $1350 \mathrm{~g}$ & $225 \mathrm{~g}$ \\
$\mathrm{M}-\left(. *^{*}\right)_{10 \mathrm{~min}}$ & $90 \mathrm{~g}$ & $10 \mathrm{~min}$ & $360 \mathrm{~g}$ & $1350 \mathrm{~g}$ & $225 \mathrm{~g}$ \\
\hline
\end{tabular}


Table 3 Characteristics for the experimental materials. ${ }^{*} \mathrm{P}$ content in $\%$ from the XRF analysis.

\begin{tabular}{|c|c|c|c|c|}
\hline & Cement & SSA & SSA-ED & $\begin{array}{l}\text { DS/EN-450-1 } \\
\text { Requirement }\end{array}$ \\
\hline Water content \% & 0.3 & 0.3 & 2.7 & \\
\hline $\mathrm{pH}$ & 12.6 & 9.3 & 3.5 & \\
\hline Water solubility \% & -3.6 & 1.5 & 1.3 & \\
\hline \multicolumn{5}{|l|}{ LOI \% } \\
\hline $550^{\circ}$ & 0.8 & 0.5 & 4.4 & \multirow[t]{2}{*}{ Max. 9.0} \\
\hline $950^{\circ}$ & 7.0 & 1.6 & 4.7 & \\
\hline \multicolumn{5}{|l|}{ Oxides \% } \\
\hline $\mathrm{P}_{2} \mathrm{O}_{5}{ }^{*}$ & $0.2\left(0.1^{*}\right)$ & $20.6\left(9^{*}\right)$ & $2.3\left(1^{*}\right)$ & - \\
\hline $\mathrm{Al}_{2} \mathrm{O}_{3}$ & 4.9 & 8.3 & 6.6 & \multirow{3}{*}{$\begin{array}{l}\mathrm{SiO}_{2}+\mathrm{Al}_{2} \mathrm{O}_{3+} \\
\mathrm{Fe}_{2} \mathrm{O}_{3}>70 \%\end{array}$} \\
\hline $\mathrm{SiO}_{2}$ & 20.1 & 18.6 & 39.4 & \\
\hline $\mathrm{Fe}_{2} \mathrm{O}_{3}$ & 5.4 & 15.7 & 27.3 & \\
\hline $\mathrm{SO}_{3}$ & 4.7 & 19.2 & 0.3 & $<3.0 \%$ \\
\hline $\mathrm{Na}_{2} \mathrm{O}$ & 0.7 & 1.2 & 0.8 & \multirow{2}{*}{ Alkalies < $5 \%$} \\
\hline $\mathrm{K}_{2} \mathrm{O}$ & 0.8 & 1.7 & 1.8 & \\
\hline $\mathrm{MgO}$ & 0.5 & 2.3 & 1.0 & - \\
\hline $\mathrm{MnO}$ & 0.04 & 0.1 & 0.01 & - \\
\hline $\mathrm{CaO}$ & 65.8 & 20.9 & 1.0 & - \\
\hline $\mathrm{TiO}_{2}$ & 0.4 & 0.9 & 1.7 & - \\
\hline $\mathrm{Cl}$ & 0.1 & 0.02 & 0.1 & Max. $0.1 \%$ \\
\hline
\end{tabular}


Table 4 Heavy metal content in the experimental materials

\begin{tabular}{lllll}
\hline Heavy metals $(\mathrm{mg} / \mathrm{kg})$ & Cement & SSA & SSA-ED & Category 3 [21] \\
\hline $\mathrm{Cd}$ & 0.45 & 2.8 & 0.5 & $>0.5$ \\
$\mathrm{Cu}$ & 67.5 & 590 & 460 & $>500$ \\
$\mathrm{~Pb}$ & 22 & 170 & 420 & $>40$ \\
$\mathrm{Zn}$ & 115 & 2100 & 2600 & $>500$ \\
\hline Heavy metal leaching $(\mu \mathrm{g} / \mathrm{l})$ & & & & \\
\hline $\mathrm{Cd}$ & $<20$ & $<20$ & $35 \pm 0.02$ & 40 \\
$\mathrm{Cu}$ & $<20$ & $<20$ & $4,730 \pm 170$ & 2,000 \\
$\mathrm{~Pb}$ & $<20$ & $<20$ & $92 \pm 11$ & 70 \\
$\mathrm{Zn}$ & $<20$ & $<20$ & $48,500 \pm 790$ & 1,500 \\
\hline
\end{tabular}


Table 5 Heavy metal leaching from crushed mortar samples

\begin{tabular}{|c|c|c|c|c|c|c|c|c|c|}
\hline & M Ref & $\begin{array}{l}\mathrm{M}- \\
\mathrm{SSA}_{0 \mathrm{sec}}\end{array}$ & $\mathrm{M}-S S A_{30 \mathrm{~s}}$ & $\begin{array}{l}\mathrm{M}- \\
\mathrm{SSA}_{10 \min }\end{array}$ & $\begin{array}{l}\text { M- } \\
\text { SSAED }_{0 \mathrm{~s}}\end{array}$ & $\begin{array}{l}\text { M- } \\
\text { SSAED }_{30 \mathrm{~s}}\end{array}$ & $\begin{array}{l}\text { M- } \\
\text { SSAED }_{10 \mathrm{~min}}\end{array}$ & $\begin{array}{l}\text { Inert } \\
\text { waste } \\
{[23]} \\
\end{array}$ & $\begin{array}{l}\text { Mineral } \\
\text { waste } \\
{[23]}\end{array}$ \\
\hline$\overline{\mathrm{pH}}$ & 12.5 & 11.6 & 12.5 & 12.4 & 12.6 & 12.6 & 12.6 & & \\
\hline $\begin{array}{l}\text { Cd } \\
(\mu g / l)\end{array}$ & $<20$ & $<20$ & $<20$ & $<20$ & $<20$ & $<20$ & $<20$ & 15 & 300 \\
\hline $\begin{array}{l}\mathrm{Cu} \\
(\mu \mathrm{g} / \mathrm{l})\end{array}$ & $<20$ & $<20$ & $22 \pm 6$ & $36 \pm 8$ & $114 \pm 11$ & $61 \pm 24$ & $<20$ & 450 & 12,500 \\
\hline $\begin{array}{l}\mathrm{Pb} \\
(\mu \mathrm{g} / \mathrm{l})\end{array}$ & $<20$ & $<20$ & $<20$ & $<20$ & $<20$ & $<20$ & $<20$ & 100 & 2,500 \\
\hline $\begin{array}{l}\mathrm{Zn} \\
(\mu \mathrm{g} / \mathrm{l})\end{array}$ & $<20$ & $<20$ & $34 \pm 3$ & $39 \pm 7$ & $128 \pm 4$ & $38 \pm 2$ & $29 \pm 0$ & 1000 & 12,500 \\
\hline
\end{tabular}

